\title{
DEVELOPMENT OF FINANCIAL MONITORING PRINCIPLES FOR INVESTMENT PROJECTS IN THE SYSTEM OF TRANSFORMATIVE CHANGES OF INDUSTRIAL ENTERPRISES \author{
ІНВЕСТИЦІЙНИХ ПРОЕКТІВ В СИСТЕМІ
} \\ РОЗВИТОК ПРИНЦИПІВ ФІНАНСОВОГО МОНІТОРИНГУ ТРАНСФОРМАЦИЙНИ ПЕРЕТВОРЕНЬ ПРОМИСЛОВИХ ПІДПРИЄМСТВ
}

UDC 338.45:33.06

https://doi.org/10.32843/infrastruct39-34

\section{Plakhotnik Olena}

Doctor of Economic Sciences, Professor,

Head at Department of Economics

and Production Organization

Dnipro State Technical University

\begin{abstract}
As a part of the internal management tools improvement for transformative changes of industrial enterprises, the principles of financial monitoring of investment projects have been developed. In the system of financial monitoring of investment projects, the need to comply the basic principles of rational financing of industrial enterprises activity has been substantiated. The approach to the organization of the budgeting system as a tool for the investment and innovation activity management of industrial enterprise with consideration of its transformative changes has been proposed. The formalization of management processes of innovative projects funding, which is a system of financial flows in the complex management of innovation activity of industrial enterprises, was further developed. The scheme of the mechanism for financial monitoring of cash flows related to the implementation of investment projects of the enterprise has been improved, which involves an analysis of the structure of financial flows when managing investment projects, their assessment at various stages of project implementation and determining the effectiveness of achieving the goals.

Key words: financial monitoring, investment project, budget planning, financial resources, market value, cash flows, equity, return on investment.
\end{abstract}

В рамках совершенствования внутренних инструментов управления транссоормационными преобразованиями промышленных предприятий, получили развитие принципы фринансового мониторинга инвестиционных проектов. В системе фринансового мониторинга инвестиционных проектов, обоснована необходимость соблюдения базовых принципов рационального финансирования деятельности промышленных предприятий. Предложен подход $к$ организации системы бюджетирования как инструмента управления инвестиционно-инновационной деятельностью промышленного предприятия с учетом его трансформационных преобразований. Получила дальнейшее развитие формализация процессов управления финансированием инновационных проектов, представляющих собой систему финансовых потоков при комплексном управлении инновационной деятельностью промышленных предприятий. Усовершенствована схема механизма фринансового мониторинга денежных потоков, связанных с реализацией инвестиционных проектов предприятия, предполагающая анализ структуры фринансовых потоков при управлении инвестиционными проектами, их оценку на различных этапах реализации проекта и определение эфрфрективности достижения поставленных целей.

Ключевые слова: фринансовый мониторинг, инвестиционный проект, бюджетное планирование, фринансовые ресурсы, рыночная стоимость, денежные потоки, собственный капитал, окупаемость инвестиций.

Активний розвиток фрінансових інновацій та інфрормаційних технологій привів до перетворення світового фрінансового простору на глобальну систему, що вимагає постійного регулювання й контролю. Регулювання у фінансовій сфрері, спрямоване на лібералізацію руху капіталу, дозволяє підвищити інвестиційну привабливість економіки країни. Ці фракти зумовили необхідність застосування заходів срінансового моніторингу, спрямованого на виявлення, попередження та припинення ризиків і загроз з боку неефективного використання капіталу в реальному секторі економіки України. У рамках вдосконалення внутрішніх інструментів управління транссоормаційними перетвореннями підприємств, отримали розвиток принципи фрінансового моніторингу інвестиційних проектів. Обгрунтовано необхідність дотримання базових принципів раціонального фрінансування діяльності підприємств у системі фрінансового моніторингу інвестиційних проектів. Доведено, що ефрективне фрункціонування підприємств пов'язане з реалізацією інвестиційних проектів, що передбачає проведення у рамках фрінансового моніторингу поглибленого аналізу елементів консолідованого грошового потоку. Фінансовий моніторинг має бути спрямований на дослідження маркетингової, операційної, логістичної, інвестиційної та інших видів діяльності, що забезпечують зростання ринкової вартості підприємства. Запропоновано підхід до організації системи бюджетування як інструменту управління інвестиційно-інноваційною діяльністю підприємства з урахуванням його трансфоормаційних перетворень. Отримало подальший розвиток фрормалізація процесів управління фрінансуванням інноваційних проектів, що представляє собою систему фінансових потоків при комплексному управлінні інноваційною діяльністю підприємств. Вдосконалена схема механізму фрінансового моніторингу грошових потоків, пов'язаних із реалізацією інвестиційних проектів підприємства, що передбачає аналіз структури фінансових потоків при управлінні інвестиційними проектами, їх оцінку на різних етапах реалізації проекту та визначення есрективності досягнення поставлених цілей.

Ключові слова: фрінансовий моніторинг, інвестиційний проект, бюджетне планування, фрінансові ресурси, ринкова вартість, грошові потоки, власний капітал, окупність інвестицій.

Formulation of the problem. The active development of financial innovations and information technologies has led to the transformation of the global financial area into a global system that requires constant regulation and control. Regulation in the financial sector, aimed at liberalizing the movement of capital, can increase the investment attractiveness of the country's economy. The solution to this problem is directly related to the increasing of capital outflows from national financial systems.

In Ukraine, due to a deficit in the aggregate balance of payments and repayment of IMF loans, international reserves decreased to 19.4 billion USD at the end of the second quarter of 2019 or to 3.2 months of future import. The stagnation of the Ukrainian economy is recognized to back to the condition of 2012 , 
when it grew by only $0.2 \%$. In 2013 , zero growth was recorded. During the acute crisis, GDP reduced by $6.6 \%$ in 2014 and by $9.8 \%$ in 2015. The recovery growth of the national economy began in 2016 when GDP grew by $2.4 \%$. In 2017 , this indicator was $2.5 \%$, in 2018 it was $3.3 \%$.

These facts predetermined the need for financial monitoring measures aimed at identifying, preventing and putting an end to the risks and threats from the inefficient use of capital in the real sector of the Ukrainian economy. That is, the economic system of Ukraine has moved to the stage associated with the need for effective financial management of transformative changes in various sectors of the economy.

Analysis of recent research and publications. The transition of the economy to an innovative path of development is ensured by the restructuring of investment mechanisms for the functioning of enterprises, increasing the importance of the processes of mastering the manufacture of new products, using new technologies and modern technology, and improving arrangement of production and management. The task of growth of innovative activity in the process of transformative changes of the Ukrainian economy requires industrial enterprises to design investment development programs $[1 ; 3]$.

This necessitates changing in approaches to market-based instruments for internal management of transformative changes, the main element of which is financial monitoring of investment projects. Financial monitoring of investment projects as an instrument of internal enterprise management is at the stage of formation, search for new solutions, theoretical generalization and development of financial science in this direction, especially when solving issues of effective functioning of an enterprise in the context of economic and political transformations.

In this context, a significant contribution to the study of financial monitoring of investment projects was made by such scientists as: I. Blank, K. Borodkin, V Bocharov, O. Vasilik, L. Drobozina, A. Podderegin, V. Kovalev, G. Savitskaya, J. C. Van Horne, J. Brighamy et al.

However, a single scientific and methodological approach that aims at building the system of effective financial monitoring of investment projects in the system of transformative changes of enterprises has not been formed yet. In this regard, the development of integrated approach to the development of the principles of financial monitoring of investment processes of an enterprise is an urgent and timely task.

The statement of the article objectives. The purpose of this article is, on the basis of systematic approach, to methodically develop the principles of financial monitoring of investment projects in the system of transformative changes of industrial enterprises aimed at increasing the financial result and efficient use of its resources, which, unlike studies in this area, allows monitoring the sources of financing of innovations and assessment of the investment attractiveness of the project, carry out the selection of possible and assess the applicable forms of financing, based on the system of standard and specific restrictions.

Outline of the basic research material. Modern management of enterprise development is based on a systematic approach, according to which the enterprise is considered as a "feedback system", that is, information on the results of the functioning of the system should be taken into account in the process of further development. Constantly functioning feedback in the enterprise management system should be considered as the process monitoring of the system functioning. During the operation of the enterprise, monitoring provides active observation of the investment development process in order to identify its compliance with target indicators based on the assessment, analysis and interpretation of a set of indicators of investment activity.

Investment project management, as a rule, refers to the management and coordination of resources, both material and labor, throughout the project life cycle by using modern management methods to achieve certain results regarding the cost, quality, volume, composition of work, their compliance with interests of project participants.

The effective functioning of the enterprise is associated with the implementation of investment projects, which provides for an in-depth analysis of the elements of the consolidated cash flow of the enterprise as part of financial monitoring [6]. In order to manage the investment cash flows of the enterprise, financial monitoring should be aimed at the study of marketing, operating, logistics, investment and other types of activities that increase the market value.

When choosing sources of funds, in the financial monitoring system of investment projects, it is necessary to observe the basic principles of rational financing $[2 ; 5]$ :

- the necessary financial resources should be at the disposal of the enterprise as long as they remain bound as a result of the implementation of the relevant investments;

- when using a commercial lending instrument (growth in accounts payable), it is necessary to ensure the possibility of extending its repayment period without prejudice to existing business relations and financial sanctions.

An important stage of financial monitoring of an enterprise in innovation and investment management is the organization of a budgeting system. The company should use a single methodology of financial planning, which includes [6]:

- justification of the structure of operational, financial and investment budgets;

- determination of the final forms of the aggregate budget of the enterprise; 
- selection of the basic method of financial planning.

In recent years, the three methods of financial planning have become most widespread in the practice of financial management: the percentage of sales method, the budget planning method, and the calculation and analytical method [7].

The essence of the percentage of sales method is to solve a dual challenge:

1. Based on the planned percentage growth in sales for the coming period, it is necessary to determine the assets, liabilities and future expenses as a percentage of sales. Often the forecast of sales is estimated as the probability distribution of possible levels of sales.

2. Balanced forecast information formats are compiled on the basis of obtained financial parameters.

The main advantage of the percentage of sales method is simplicity and clarity. The main restrictions of the method are the following: the assumptions that the company is constantly working at full capacity and that only capital investments are needed to increase sales are not sufficiently substantiated; all related resources are balanced; if the company has undercharged assets, the use of this method causes an increase in the degree of undercharging, which can lead to serious distortions in the final parameters of the entire financial plan.

The method of budget planning consists in the fact that the construction of forecast forms of financial reporting is carried out on the basis of the calculation of each element of assets, liabilities, income and expenses with the help of auxiliary budgets, combined into a group of operating budgets.

The budget planning process is carried out in two stages: preparation of the operating budget and preparation of the financial budget.

The operating budget consists of the following budgets: sales budget; production budget; inventory budget; direct costs budget for materials; production overhead cost budget; budget of direct costs for labor; business expenses budget; management budget; profit and loss statement.

The financial budget consists of the following financial documents: cash flow budget and balance sheet.

Despite the deep study of the budget planning method and widespread in Western practice, its application in modern domestic practice present challenges, which is caused by a number of reasons:

1. In practice, domestic enterprises often fail to comply with the "golden rule" of financing, considered above as the basic condition for building the financial planning system as a whole.

2. The method is based on the assumption that there is an equilibrium state in the market economy, which can significantly reduce the significance of the fundamental financial contradiction.
Calculation and analytical method of financial planning based on the matrix balance involves:

- conversion of the standard balance to the matrix balance;

- selection of financing sources according to the "golden rule" of financing in the forecast matrix balance sheet with their simultaneous reflection in the cash flow forecast. During this operation, the necessary structure and amount of funding sources are identified, which are further subject to optimization;

- selection of the missing sources of financing and substantiation of their content during the formation of the third section of the cash flow forecast, intended to complete the final balancing of all parameters of the financial plan. Therefore, the forecast balance is performed until the cash flow forecast is completed;

- transformation of the constructed forecast matrix balance back into the balance of the standard format. A forecast report on cash flows of the enterprise is drawn up on the basis of the standard forecast balance sheet and the forecast profit and loss statement;

- assessment of the effectiveness of the planned scenario using financial ratios and the preparation of an aggregate analytical paper.

For the specific conditions of each enterprise on the basis of the matrix balance model, the best option for current assets and the optimal scheme for their financing can be chosen. For these purposes, the optimal parameters of the matrix balance can be calculated using the algorithm of the "transportation problem". Advantages of this method:

1. The matrix balance allows you to take into account or exclude most of the uncertainties (risks) that are characteristic of emerging markets.

2. This method is based on the planning methodology from what has been achieved, but this is done on the basis of the results of the cash flow restructuring, which significantly increases the reliability of the planning results.

3. The formation of asset items of the forecast balance using this method simultaneously solves the problem of optimizing the structure of working capital.

4. The practical implementation of the "golden" rule of financing in this method leads to strict requirements to ensure a number of financial proportions in the balance sheet, strict correspondence of certain assets and liabilities.

5. The application of the concept of matrix modeling greatly facilitates the task of building a forecast balance. Matrix forecasting models make it possible to widely use a large number of restrictions on financial proportions and a developed economic and mathematical apparatus.

The main sources of financing the investment development of an enterprise include:

- own funds of the enterprise (reinvested part of profit, depreciation charges, insurance amounts for damages, funds from the sale of non-material assets); 
- attracted funds (issue of shares and other valuable papers, contributions, donations, funds provided on a non-refundable basis);

- borrowed funds (budget, commercial, bank loans).

Financial resources obtained from various sources must be optimized as part of the company's total liabilities quantitatively and structurally. To do this, the method of assessing the market capital value is used.

Financing of investment activities may take various forms (state financing, equity financing, bank loans, venture financing, leasing, forfeiting, mixed financing), therefore, it is necessary to formalize management function of investment resources for providing their effective use and reflexivity of loan capital which ensure the optimal solution for each specific investment project regarding one form of its financing or another, their combinations, coordination of their joint use.

Based on the presented scheme of organizing the financing of investment projects, it is necessary to formalize the relevant processes, which are a system of financial flows in the integrated management of innovative projects.

Let us summarize all the above-considered components of the management mechanism for the implementation of investment projects in Fig. 1, on which a formalized scheme of the mechanism for financial monitoring of cash flows related to the implementation of investment projects of the enterprise is presented.

This scheme assumes the analysis both of the structure of financial flows directly when managing the investment projects, and also includes the assessment of different stages of project implementation. The initial stage of the mechanism is monitoring the sources of financing of innovations and evaluation of the project investment attractiveness, which are based on such basic components as:

- adjusted to the specifics of a particular industry, market segment, on which an innovative project is implemented (promoted), a system for the comprehensive assessment of this project;

- risk analysis, examination of a separate innovation project according to the risk criterion;

- examination of a separate innovation project according to the criterion of efficiency (profitability);

- examination of a separate innovation project according to the criterion of liquidity (profitability);

- a preliminary study of the viability of an innovative project (determining the project feasibility based on cost and planned profit (economic, social, etc.));

- analysis of the dynamics of the investment project (for already implemented programs). It must ensure the implementation of the project with regard to temporary and financial restrictions.

The matrix of the decision-making process when choosing the final set of funding sources and its chosen form completes this part of the process of modeling the object of study. The matrix methodizes and specifies the totality of possible sources of financial resources in relation to the previously selected form of investment of an innovative project.

The process of attracting financing for the implementation of an investment project must take into account the specifics of the enterprise. These specific features include: the long term for the implementation of investment projects by high-tech manufacturing enterprises, the large share of the research and development cost in the cost of the entire project, the distorted balance sheet of the enterprise (at the initial stage of the project, it seems possible to take such a balance structure acceptable for enterprises implementing long-term investment projects).

The basis of this approach is the provisions on the financial project feasibility, together with the need to prevent the risk of financial stability of the enterprise.

That is why it is rational to optimize the capital structure of the enterprise, based on the timing, cost and impact on the balance sheet structure of the enterprise with the necessary condition for maintaining the effectiveness of the investment project. These provisions substantiate the need to develop and implement methods for attracting financing for investment project.

The method of attracting financing includes the following steps:

1. Determining the need for additional financing: the required amount and directions of use.

2. Determination of financing methods acceptable for use at this stage of the project, taking into account the expanded classification of financial flows and the impact of financing methods on the performance of the enterprise.

3. Analysis of possible methods of financing through cash flows.

4. Analysis through the calculation of financial ratios.

5. Analysis through a change in financial condition.

6 . The choice of the recommended method of financing. The criteria for the acceptability of the method at this stage of the investment project are the sufficiency of the inflow by this method to cover the need for additional financing.

The next stage in financial monitoring of financial flows management when investing in innovations is the formation of organizational elements, such as the establishment of a focal point. Then, a system of contractual obligations is emerging, conditions and restrictions are defining between all entities participating in the management system for the implementation of the innovation project.

A number of principles should be highlighted, with which compliance is fundamental for financial flows management in the enterprises implementing longterm investment projects:

- inward and outward financial flows must correspond to the declared (in size, sources, directions of 


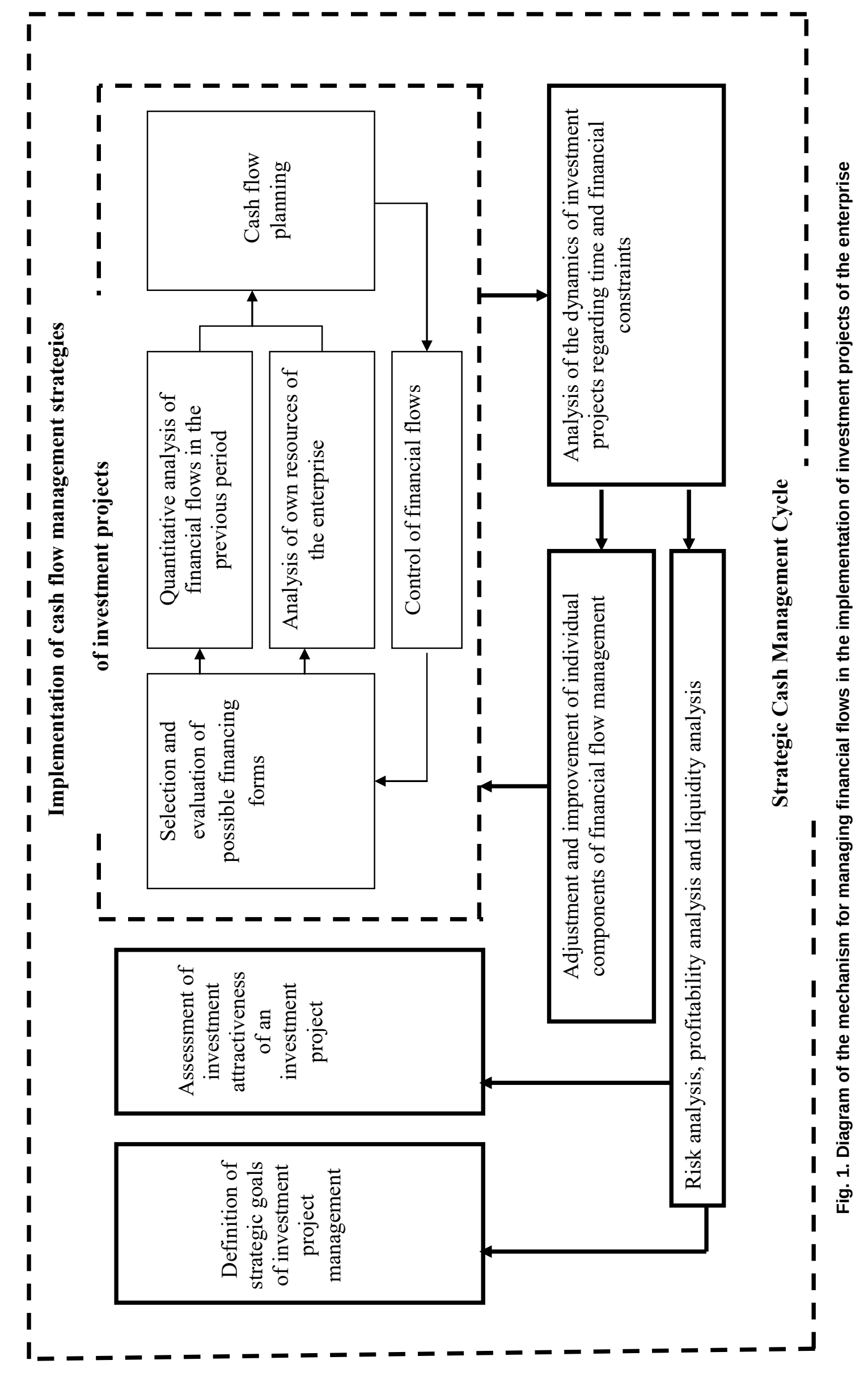


use and cost) in the business plan for the implementation of the investment project;

- retrospective analysis of the data is not informative, since at each stage of the investment project new tasks are solved and the company's turnover is growing rapidly;

- management of financial flows should be based on the principle of financial feasibility of the project;

- when managing financial flows, it is necessary to take into account their influence on the capital structure of the company, its financial independence and credit attractiveness. Compliance with this principle is especially important for enterprises at the initial stage of implementation of investment projects, when there is no revenue for the products sold, and its activity is highly dependent on borrowed funds.

Constant monitoring of the process of implementing the innovation with the possibility to adjust individual management parameters and the ability to change individual elements of its system, which is indicated in the scheme under consideration, is indispensable.

Conclusions. Thus, the study at the methodological level allowed us to prove that:

- the effective functioning of the enterprise is associated with the implementation of investment projects, which provides for an in-depth analysis of the elements of the consolidated cash flow of the enterprise during financial monitoring. In order to manage the investment cash flows of an enterprise, financial monitoring should be aimed at studying marketing, operating, logistics, investment and other types of activities that increase the market value of the enterprise;

- an important stage of financial monitoring of an enterprise in the investment management is the organization of a budgeting system. In this regard, the use of a unified methodology of financial planning is proposed;

- based on the synthesis of the elements of the management process for the implementation of investment projects, the formalized scheme of the mechanism for financial monitoring of cash flows related to the implementation of investment projects of the enterprise has been improved, which involves an analysis of the structure of financial flows during the management of investment projects, their assessment at the different stages of implementation and the determination of the effectiveness of the implementation and achievement of the goals;

- in the system of transformative changes of industrial enterprises, a promising direction in the further study of the financial monitoring issue as a part of innovative projects is the development of a financial resources management mechanism that provides a comprehensive analysis of the potential and real attractiveness of the innovative projects according to the system of absolute and relative terms, expert evaluation.

\section{REFERENCES:}

1. Belousov V. I., Belousov A. V., Ivanov S. V. (2017) Innovatsionnoe predprinimatel'stvo (biznes): teoriya i praktika : monografiya. Voronezh: Istoki. (in Russian)

2. Egorov P. V., Serdyuk-Kopchekchi Yu. V. (2014) Mekhanizm upravleniya finansovym potentsialom promyshlennykh predpriyatiy. Donetsk : OOO «YugoVostok», Ltd. (in Ukrainian)

3. Illiashenko S. M., Bilovodska O. A. (2010) Upravlinnia innovatsiinym rozvytkom: monohrafiia. Sumy: Universytetska Knyha. (in Ukrainian)

4. Liakhovych L. A. (2012) Monitorynh Investytsiinykh Proektiv Pidpryiemstv. Innovatsiina Ekonomika. Ternopil, 5' [31] pp. $249-251$.

5. Kodatskiy V.P. (2015) Finansovyy menedzhment. Kharkov.: Khar'kovskoe otd-nie izdatel'stva «Ehkonomika» pri Khar'kovskom ehkonomicheskom institute. (in Ukrainian)

6. Joseph M. Juran Made in U. S. A.: A Renaissance in Quality. Harvard Business Review. July - August, 2008. P. 45.

7. Schwager Jack D., Turner Steven C. A study Guide for Fundamental Analysis. $1_{\text {st }}$ ed. John Wiley\&Sons, 2004. 186 p.

\section{БІБЛІОГРАФІЧНИЙ СПИСОК:}

1. Белоусов В. И., Белоусов А. В., Иванов С. В. Инновационное предпринимательство (бизнес): теория и практика : монография. Воронеж: Истоки, 2017. 319 c.

2. Егоров П. В., Сердюк - Копчекчи Ю. В. Механизм управления фринансовым потенциалом промышленных предприятий: монография. Донецк : ООО «Юго-Восток», Лтд, 2014. 152 с.

3. Ілляшенко С. М., Біловодська О. М. Управління інноваційним розвитком : монограсрія. Суми : Університетська книга, 2010. 281 с.

4. Ляхович Л. А. Моніторинг інвестиційних проектів підприємств. Інноваційна економіка. Тернопіль., 5'2012 [31] С. 249 - 251.

5. Кодацкий В. П. Финансовый менеджмент. Харьков : Харьковское отд-ние издательства «Экономика» при Харьковском экономическом институте, 2015. 212 c.

6. Joseph M. Juran Made in U. S. A.: A Renaissance in Quality. Harvard Business Review. July - August, 2008. P. 45.

7. Schwager Jack D., Turner Steven C. A study Guide for Fundamental Analysis. $1_{\text {st }}$ ed. John Wiley\&Sons, 2004. 186 p. 